\title{
Tool wear and cost evaluation of face milling grade 5 titanium alloy for sustainable machining
}

\author{
Masood, I. ${ }^{\mathrm{a},{ }^{*}}$, Jahanzaib, M. ${ }^{\mathrm{a}}$, Haider, A. ${ }^{\mathrm{a}}$ \\ ${ }^{a}$ Industrial Engineering Department, University of Engineering and Technology, Taxila, Pakistan
}

\begin{abstract}
A B S T R A C T
Cutting tool life, its wear rate and machining cost play significant role in a machining process. Effect of these parameters using face milling of titanium alloy is analysed to assess the economic factor of sustainability. Machining sustainability of Ti-6Al-4V hardened to 55 HRC is assessed through a novel technique of iso-response method, in which the response value, i.e. surface finish is taken as criteria for evaluation and comparison among dry, conventional and cryogenic machining. Experiments are designed in DOE for central composite design and performed face milling of Ti-6Al-4V with PVD coated carbide inserts using three conditions of cooling and measured the response values. Feed, speed, and depth of cut were used as input variables. Comparing the average results of tool life and machining cost for iso-response technique, it was found that $47.55 \%$ less electricity cost and $47.59 \%$ less machine operating cost and 10.76 times increased cutting tool life achieved for cryogenically cooled experiments as compared with dry machining. Coolant cost was found 13.33 times cheaper for cryogenic as compared with conventional machining. The results indicate that cryogenic cooling is more sustainable for tool life, having better surface finish of machined part with least energy and machining cost.
\end{abstract}

\section{ARTICLE INFO}

Keywords:

Titanium alloy

Milling

Sustainable machining

Machining cost

Tool life

*Corresponding author: imranmasood76@gmail.com

(Masood, I.)

Article history:

Received 12 April 2016

Revised 15 August 2016

Accepted 23 August 2016

(C) 2016 PEI, University of Maribor. All rights reserved.

\section{References}

[1] Shokrani, A., Dhokia, V. Newman, S.T. (2012). Environmentally conscious machining of difficult-to-machine materials with regard to cutting fluids, International Journal of Machine Tools and Manufacture, Vol. 57, 83-101, doi: 10.1016/i.ijmachtools.2012.02.002.

[2] Jaffery, S.I., Mativenga, P.T. (2009). Assessment of the machinability of Ti-6Al-4V alloy using the wear map approach, The International Journal of Advanced Manufacturing Technology, Vol. 40, No. 7-8, 687-696, doi: 10.1007/s00170-008-1393-9.

[3] Zhang, S., Li, J.F., Wang, Y.W. (2012). Tool life and cutting forces in end milling Inconel 718 under dry and minimum quantity cooling lubrication cutting conditions, Journal of Cleaner Production, Vol. 32, 81-87, doi: 10.1016/i.jclepro.2012.03.014.

[4] Jayal, A.D., Badurdeen, F., Dillon, O.W., Jawahir, I.S. (2010). Sustainable manufacturing: Modeling and optimization challenges at the product, process and system levels, CIRP Journal of Manufacturing Science and Technology, Vol. 2, No. 3, 144-152, doi: 10.1016/i.cirpj.2010.03.006.

[5] Shokrani, A., Dhokia, V., Newman, S.T. (2016). Investigation of the effects of cryogenic machining on surface integrity in CNC end milling of Ti-6Al-4V titanium alloy, Journal of Manufacturing Processes, Vol. 21, 172-179, doi: 10.1016/i.jmapro.2015.12.002.

[6] Yildiz, Y. Nalbant, M. (2008). A review of cryogenic cooling in machining processes, International Journal of Machine Tools and Manufacture, Vol. 48, No. 9, 947-964, doi: 10.1016/j.ijmachtools.2008.01.008.

[7] Lawal, S.A., Choudhury, I.A., Nukman, Y. (2012). Application of vegetable oil-based metalworking fluids in machining ferrous metals-a review, International Journal of Machine Tools and Manufacture, Vol. 52, No. 1, 1-12, doi: 10.1016/i.ijmachtools.2011.09.003. 
[8] Abdalla, H., Baines, W., McIntyre, G., Slade, C. (2007). Development of novel sustainable neat-oil metal working fluids for stainless steel and titanium alloy machining. Part 1. Formulation development, The International Journal of Advanced Manufacturing Technology, Vol. 34, No. 1, 21-33, doi: 10.1007/s00170-006-0585-4.

[9] Dhar, N.R., Kamruzzaman, M., Khan, M.M.A., Chattopadhyay, A.B. (2006). Effects of cryogenic cooling by liquid nitrogen jets on tool wear, surface finish and dimensional deviation in turning different steels, International Journal of Machining and Machinability of Materials, Vol. 1, No. 1, 115-131, doi: 10.1504/IJMMM.2006.010662.

[10] Da Silva, F.J., Franco, S.D., Machado, Á.R., Ezugwu, E.O., Souza Jr, A.M. (2006). Performance of cryogenically treated HSS tools, Wear, Vol. 261, No. 5-6, 674-685, doi: 10.1016/i.wear.2006.01.017.

[11] Çakır, O., Kıyak, M., Altan, E. (2004). Comparison of gases applications to wet and dry cuttings in turning, Journal of Materials Processing Technology, Vol. 153-154, 35-41, doi: 10.1016/i.jmatprotec.2004.04.190.

[12] Gunda, R.K., Reddy, N.S.K., Kishawy, H.A. (2016). A novel technique to achieve sustainable machining system, Procedia CIRP, Vol. 40, 30-34, doi: 10.1016/i.procir.2016.01.045.

[13] Herrmann, C., Hesselbach, J., Bock, R., Zein, A., Öhlschläger, G., Dettmer, T. (2007). Ecologically benign lubricants - Evaluation from a life cycle perspective, CLEAN-Soil, Air, Water, Vol. 35, No. 5, 427-432, doi: 10.1002/clen. 200720025.

[14] Gayretli, A., Abdalla, H. (1999). A prototype constraint-based system for the automation and optimization of machining processes, Proceedings of the Institution of Mechanical Engineers, Part B: Journal of Engineering Manufacture, Vol. 213, No. 7, 655-676.

[15] Pusavec, F., Kramar, D., Krajnik, P., Kopac, J. (2010). Transitioning to sustainable production - part II: Evaluation of sustainable machining technologies, Journal of Cleaner Production, Vol. 18, No. 12, 1211-1221, doi: 10.1016/i.jclepro.2010.01.015.

[16] Pušavec, F. Kopač, J. (2011). Sustainability assessment: cryogenic machining of Inconel 718, Strojniški vestnikJournal of Mechanical Engineering, Vol. 57, No. 9, 637-647, doi: 10.5545/sv-jme.2010.249.

[17] Park, K.-H., Yang, G.-D., Suhaimi, M.A., Lee, D.Y., Kim, T.-G., Kim, D.-W., Lee, S.-W. (2015). The effect of cryogenic cooling and minimum quantity lubrication on end milling of titanium alloy Ti-6Al-4V, Journal of Mechanical Science and Technology, Vol. 29, No. 12, 5121-5126, doi: 10.1007/s12206-015-1110-1.

[18] Yan, L., Yuan, S., Liu, Q. (2012). Influence of minimum quantity lubrication parameters on tool wear and surface roughness in milling of forged steel, Chinese Journal of Mechanical Engineering, Vol. 25, No. 3, 419-429, doi: 10.3901/CJME.2012.03.419.

[19] Weinert, K., Inasaki, I., Sutherland, J.W., Wakabayashi, T. (2004). Dry machining and minimum quantity lubrication, CIRP Annals-Manufacturing Technology, Vol. 53, No. 2, 511-537, doi: 10.1016/S0007-8506(07) 60027-4.

[20] Skerlos, S.J., Hayes, K.F., Clarens, A.F., Zhao, F. (2008). Current advances in sustainable metalworking fluids research, International Journal of Sustainable Manufacturing, Vol. 1, No. 1-2, 180-202, doi: 10.1504/IJSM. 2008.019233.

[21] Sun, S., Brandt, M., Dargusch, M.S. (2010). Machining Ti-6Al-4V alloy with cryogenic compressed air cooling, International Journal of Machine Tools and Manufacture, Vol. 50, No. 11, 933-942, doi: 10.1016/i.ijmachtools. 2010.08.003.

[22] Shokrani, A., Dhokia, V., Newman, S. (2012). Study of the effects of cryogenic machining on the machinability of Ti-6Al-4V titanium alloy, In: 12th International Conference of the European Society for Precision Engineering and Nanotechnology, Bedford, UK, 283-286.

[23] Josyula, S.K., Narala, S.K.R., Charan, E.G., Kishawy, H.A. (2016). Sustainable machining of metal matrix composites using liquid nitrogen, Procedia CIRP, Vol. 40, 568-573, doi: 10.1016/i.procir.2016.01.135.

[24] Venugopal, K.A., Paul, S., Chattopadhyay, A.B. (2007). Growth of tool wear in turning of Ti-6Al-4V alloy under cryogenic cooling, Wear, Vol. 262, No. 9-10, 1071-1078, doi: 10.1016/i.wear.2006.11.010.

[25] Kopac, J., Pusavec, F. (2009). Sustainability spirit in manufacturing/machining processes, In: Portland International Conference on Management of Engineering \& Technology, Portland, Oregon, USA, 1197-1205, doi: 10.1109/PICMET.2009.5262015.

[26] Deiab, I., Raza, S.W., Pervaiz, S. (2014). Analysis of lubrication strategies for sustainable machining during turning of titanium Ti-6Al-4V alloy, Procedia CIRP, Vol. 17, 766-771, doi: 10.1016/j.procir.2014.01.112.

[27] Aramcharoen, A., Chuan, S.K. (2014). An experimental investigation on cryogenic milling of Inconel 718 and its sustainability assessment, Procedia CIRP, Vol. 14, 529-534, doi: 10.1016/j.procir.2014.03.076.

[28] Hong, S.Y., Markus, I., Jeong, W.-c. (2001). New cooling approach and tool life improvement in cryogenic machining of titanium alloy Ti-6Al-4V, International Journal of Machine Tools and Manufacture, Vol. 41, No. 15, 2245-2260, doi: 10.1016/S0890-6955(01)00041-4. 


\title{
Obraba orodja in stroškovno ovrednotenje čelnega rezkanja titanove zlitine (razred 5) za trajnostno obdelavo
}

\author{
Masood, I. ${ }^{a,}{ }^{,}$, Jahanzaib, M. ${ }^{a}$, Haider, A. ${ }^{a}$ \\ ${ }^{a}$ Industrial Engineering Department, University of Engineering and Technology, Taxila, Pakistan
}

\section{POVZETEK}

Življenjska doba orodja, njegova obraba in stroški obdelave igrajo pomembno vlogo pri obdelovalnih postopkih. $\mathrm{V}$ tej raziskavi smo analizirali vpliv teh parametrov na ekonomske dejavnike trajnostne obdelave. Za ocenjevanje stopnje trajnostne obdelave smo obdelovali titanovo zlitino Ti-6Al-4V, utrjeno na 55 HRC, kjer smo za najpomembnejše merilo izbrali površinsko hrapavost, primerjali pa smo tri različne možnosti hlajenja, in sicer hlajenje z zračnim tokom, konvencionalno hlajenje in kriogensko hlajenje. Eksperiment smo izvedli v skladu z metodologijo načrtovanja eksperimentov (angl. DOE). Šlo je za čelno rezkanje titanove zlitine Ti-6Al-4V, kjer smo za orodje uporabili rezkalo s ploščicami, ki so bile prevlečene s PVD karbidno prevleko. Vhodni parametri so bili podajanje, obdelovalna hitrost in globina reza. S primerjanjem povprečnih rezultatov življenjske dobe orodja in stroškov obdelave smo ugotovili, da so primeru kriogenskega hlajenja (v primerjavi s hlajenjem z zračnim tokom) stroški električne energije za $47.55 \%$ manjši, za $47.59 \%$ pa so manjši tudi obdelovalno-operacijski stroški, prav tako pa se je za 10.76krat podaljšala življenjska doba orodja. Stroški kriogenskega hlajenja so bili za 13.33-krat nižji kot tedaj, ko smo uporabili konvencionalno hlajenje. Rezultati kažejo, da kriogensko hlajenje podaljšuje življenjsko dobo orodja, omogoča boljšo površinsko kakovost obdelanih kosov, vse to pa dosežemo ob nižjih stroških za vloženo energijo in obdelavo.

\section{PODATKI O ČLANKU}

Ključne besede:

Titanova zlitina

Rezkanje

Trajnostna obdelava

Stroški obdelave

Življenjska doba orodja

*Kontaktna oseba: imranmasood76@gmail.com

(Masood, I.)

Zgodovina članka:

Prejet 12. aprila 2016

Popravljen 15. avgusta 2016

Sprejet 23. avgusta 2016 